Florida International University FIU Digital Commons

$3-27-2018$

\title{
Identification Through Movement: Dance as the Embodied Archive of Memory, History, and Cultural Identity
}

Lauren D. Romaguera

Florida International University, lroma013@fiu.edu

DOI: $10.25148 /$ etd.FIDC004094

Follow this and additional works at: https://digitalcommons.fiu.edu/etd

\section{Recommended Citation}

Romaguera, Lauren D., "Identification Through Movement: Dance as the Embodied Archive of Memory, History, and Cultural Identity" (2018). FIU Electronic Theses and Dissertations. 3666.

https://digitalcommons.fiu.edu/etd/3666 


\title{
FLORIDA INTERNATIONAL UNIVERSITY
}

\author{
Miami, Florida
}

\section{IDENTIFICATION THROUGH MOVEMENT: DANCE AS THE EMBODIED ARCHIVE OF MEMORY, HISTORY, AND CULTURAL IDENTITY}

\author{
A thesis submitted in partial fulfillment of \\ the requirements for the degree of \\ MASTER OF ARTS \\ in \\ ENGLISH \\ by \\ Lauren Danielle Romaguera
}

2018 
To: Dean Michael R. Heithaus

College of Arts, Sciences and Education

This thesis, written by Lauren Danielle Romaguera, and entitled Identification Through Movement: Dance as the Embodied Archive of Memory, History, and Cultural Identity, having been approved in respect to style and intellectual content, is referred to you for judgment.

We have read this thesis and recommend that it be approved.

Martha Schoolman

Heather Russell

Ana Luszczynska, Major Professor

Date of Defense: March 27, 2018

The thesis of Lauren Danielle Romaguera is approved.

Dean Michael R. Heithaus
Arts, Sciences and Education

Arts, Sciences and Education

Andrés G. Gil

Vice President for Research and Economic Development and Dean of the University Graduate School

Florida International University, 2018 


\title{
ABSTRACT OF THE THESIS \\ IDENTIFICATION THROUGH MOVEMENT: DANCE AS THE EMBODIED ARCHIVE OF MEMORY, HISTORY, AND CULTURAL IDENTITY
}

\author{
by
}

Lauren Danielle Romaguera

Florida International University, 2018

Miami, Florida

\section{Professor Ana Luszczynska, Major Professor}

This thesis focuses on legitimizing performances as a part of History and the archive. This project explores how Caribbean dance styles, particularly the rumba, not only encompass embodied cultural memory, but resemble the fluidity of culture and History. In this thesis, I explore how movement supplies a nonteleological telling of history that actively combats its traditionally linear discourse. From this examination, the thesis goes on to question the role of the rumba in a historical and cultural context. I make the argument that such extralinguistic accounts of history cannot be textually represented, nor made linguistically retrievable. Thus, they are neglected from the archive. I propose that while these sites do not fit the traditional confines of the master narrative, they should be accounted for as new meanings and/or iterations of a communal discourse of History. 
TABLE OF CONTENTS

CHAPTER

PAGE

Identification Through Movement: Dance as the Embodied Archive of Memory, History, and Cultural Identity................................................................ 1

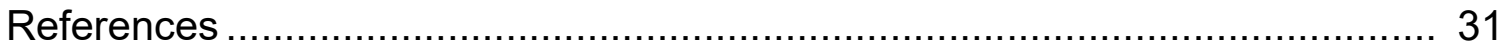


Identification Through Movement: Dance as the Embodied Archive of Memory, History, and Cultural Identity

Historical and literary artifacts are the primary materials in the archive that determine culture and history. Archivable documents are legitimized as authoritative accounts of historical events. The incessant obsession with History results in the compiling of tangible "evidence" that allegedly proves that something really happened. The monolithic discourse that dictates history is violent, as it inevitably results in the massive silencing of voices. Against such a monologic vision of History, we must understand that no singular moment will be experienced the same by all, and that all accounts of traditional History are inevitably subjective. The Western belief that there is a unified telling of historical events silences the vast majority of people. Post-colonial accounts of history work to shed light on the voices that have been silenced, and legitimize the voices of the oppressed. History has the tendency to erase those who have been "other-ed," on the basis of race, gender, sexuality, class, and physical ability. History, and the archive, neglect the voices of the other and prioritize a produced monolithic voice of the oppressor. The oppressed individuals, or subaltern ${ }^{1}$, have limited accessibility to power and are left with no access to hegemonic power. How can the oppressed achieve legitimization of their histories? Are there outlets that tell stories of "the other" and combat the received traditional conventions of historical writing?

\footnotetext{
'See Gayatri Chakravorty Spivak's "Can the Subaltern Speak."
} 
Other outlets, such as dance, music, and food are important cultural markers that offer counterhistories to the master narrative that is solely provided; for there are various ways to trace history. In this project, I examine how dance, specifically the Cuban rumba, demystifies traditional conventions of history and culture, in an attempt to reclaim performance as a legitimate site of telling, accessible to, and therefore emblematic of, a more democratic account of history and "reality." Dance allows multiple historical narratives to be heard and does not let marginalized perspectives be silenced. Throughout this project, I will explore the ways in which performance, particularly the rumba, allows for the body to become a place of memory. Dance offers a site of production of cultural memory, which ensures that no voice can be forgotten or erased. The dancing body is the object of history re-membered, and allows all people, including the subaltern, to be readable components of history.

The term "subaltern" was the crux of Gayatri Chakravorty Spivak's "Can the Subaltern Speak." In this article, Spivak produced a fundamental shift in postcolonial studies, as she refers to many aspects that legitimize a theoretical lens. Spivak writes of issues of class, race, gender, and geographical location that actively play an impactful role in the process of legitimization. For example, she identifies how theories created by Western, upper-class individuals are placed as the universal form. Certain voices are privileged over others, which in turn results in the mass silencing or neglecting of anyone who is different. Through literary and historical pursuits, Spivak sheds light on perspectives that have resulted in the silencing of entire populations. 


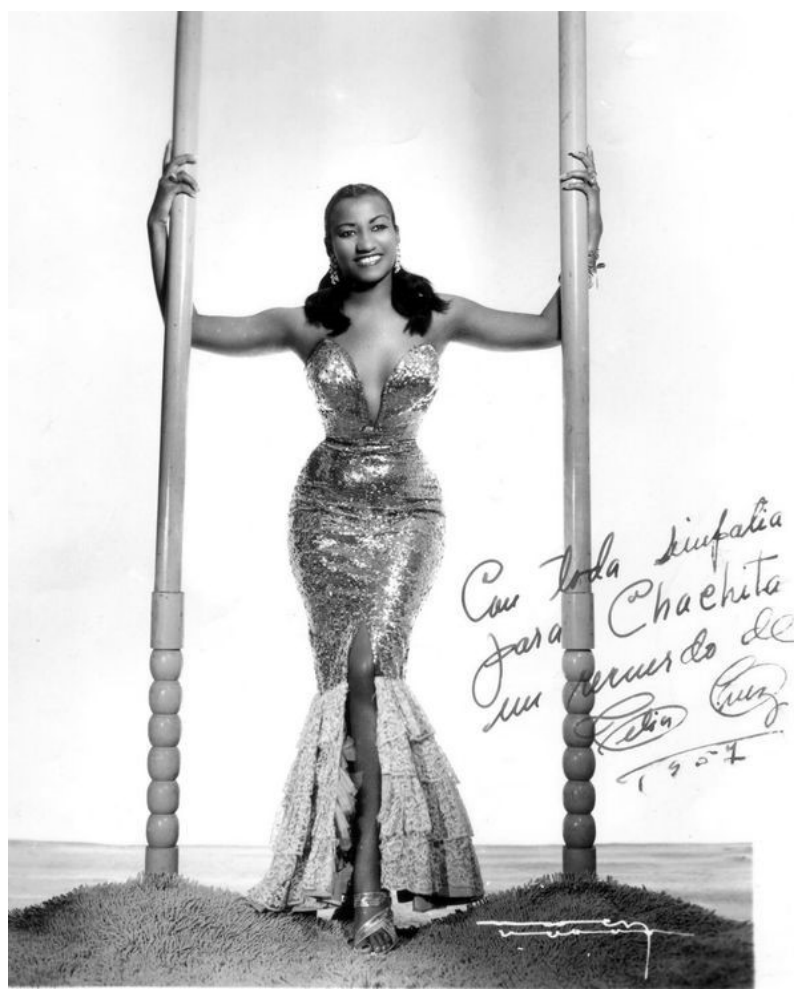

Ibrahim Arce. Celia Cruz in Havana. Photograph. ARTstor. 1957.

In Cuba, musicians such as Celia Cruz and Beny Moré are noted as ambassadors of Cuban music. Their works have portrayed a cultural marker of Cuba, all the while adding onto the cultural identity of the island. It would be impossible to explore the importance of the rumba in Cuban culture without mentioning Celia Cruz's name. Referred to as "Mother Rumba" or the "Queen of Rumba," Cruz has many ties to the dance and all it represents. The archive of Cruz's music includes multiple songs that indicate the particular performative power of the rumba, in terms of Cuban culture and Cuban identity. Cruz's cover of Gloria Gaynor's “I Will Survive”, entitled "Yo viviré," refers to the importance the dance has to the island's history. Within the second verse, Cruz reframes the lyrics to fit her personal narrative. She sings 
"Y oye mi son mi viejo son

tiene la clave de cualquier generación

en el alma de mi gente

en el cuero del tambor

en las manos del conguero

en los pies del bailador" (Cruz).

This verse translates to

"And hear my sound, my old sound

it has the key of any generation

in the soul of my people

in the leather of the drum

in the hands of conguero

in the feet of the dancer" (Cruz, translation mine).

Within this verse, Cruz refers to the importance music and dance have to the island. It is crucial to remember that every culture has its own set of unique cultural markers that make the culture what it is. These markers hold extreme relevance and should not be deemed nothing, for they hold weight and offer us a different insight of historical tellings. Cruz's reference to her living through the feet of a dancer is telling of the value the rumba has in Cuban history, and how it has repeatedly shaped the culture. When referring to the culture of an island, can dance be considered a legitimate telling of history? Is history only authenticated if it is archivable? 
Dismantling the Confines of the Archive

In the archive, as it is traditionally conceived, tangible accounts of written History, such as written documentation, are believed to signify an essential account of history and as such, occupy a privileged place. Are memories, music, performances, and oral accounts of history not legitimate sources of culture? The ways in which history is considered automatically dictate what is valued, and therefore deemed true. History is considered synonymous with the past, as it signifies a linear and chronological telling of events that have shaped all culture, and therefore the world as a whole. The linear and chronological fixity of these accounts result in a teleological and monological form.

Are there mediums, other than textual documentation, that can be legitimized as historical tellings? In many cultures, oral history is of utmost importance. Oral histories have been archived and exemplify how various perspectives exist around a singular event. As French historian Jacques Le Goff explores in History and Memory, "today documents include the spoken word, images, and gestures" (xvii). Oral archives have been developed and continue to be accounted for. What other outlets of telling can be accounted for as well? Textbook accounts of history follow a phallogocentric, hegemonic, and linear discourse, forcibly erasing anything deemed as other. As represented in Cruz's lyrics above, dance has always already been a part of Cuban heritage, and does not adhere to the confines of the archive. Although it is a different form of history, we must acknowledge it as a legitimate source. 
History with a Capital "H"

As theorists such as Jose Esteban Munoz, Diana Taylor, and Ramon Rivera-Servera demonstrate, performances offer insights that written texts cannot. Performance is a way to fill in the gaps that a monolithic History has enforced. Music, dance, and oral history are performative in the ways they remember, forget and reinvent the ways in which we view history. Throughout this project, I capitalize the notion of History to denote the fixity the terms presuppose. In Caribbean Discourse, Edouard Glissant capitalizes the "H" in History to accentuate the distinctions of what is and what is not considered a legitimate source of History. In "The Quarrel with History," Glissant states that "History [with a capital $\mathrm{H}$ ] ends where the histories of those peoples once reputed to be without history come together. History is a highly functional fantasy of the West, originating at precisely the time when it alone 'made' the history of the World" (64). Glissant's claim emphasizes how teleological the term "History" is, and how it is often viewed as essential, leaving no room for reinterpretation or multiplicity. Performance by contrast allows the space for the making, remaking, and transformation of history, collective memory, and culture. In this regard, movement ruptures and interrupts the very notions of a hierarchal linear discourse, and perceives the physical body as a vessel of marginalized experiences. Such extralinguistic accounts of history cannot be textually represented, nor made linguistically retrievable, thus they are neglected from the archive. I propose that while these sites do not fit the traditional confines of the 
master narrative, they should be accounted for as new meanings and/or iterations of a communal discourse of history.

Dance's Embodiment in Culture and Memory

Dance permits the embodiment of culture and memory, as these they are explicitly performed by the physical body. Prescriptive identities often result in the harsh and reductive labeling of a person, regarding their race, gender, class, and sexual orientation. The aforementioned identifying aspects are performative to begin with. In this regard my study juxtaposes dance and culture together, in an attempt to explore the ways in which embodied acts expand a traditional conception of identity, culture, and cultural memory. Are elements such as memory, culture, and History as performative as the rumba? These loaded terms should not be considered as mutually exclusive from performance, as movement has always already been present in every historical event, culture, and memory.

We must remember that History is unable to capture lived events, for as movement is captured it is no longer in motion. The capturing of these events allow them to be archivable, but negates the fluid performativity they encompass. I propose that we must think about performance in historical terms and as transmitters of knowledge. Traditionally, cultural history is solely transmitted by the literate and powerful. Performance is a way to corporeally manifest multiple narratives of cultural memory and history. Performing embodied memory transgresses the static and fixed notions of essentialized culture and reveals it as movement. This then allows the performing body to permeate the spaces where 
privileged accounts of History neglect the others. Dance necessitates reinterpretation and re-creation, as moves are constantly made and remade as they are practiced and performed. Though certain dances refer to a set of choreographed steps, no dance will ever, in and of itself, be performed exactly the same. I argue that considering choreography as a critical term illuminates the potential connections between memory, dance, and culture.

\section{Performativity of Culture}

We must ask ourselves: is Latinidad, or any cultural designation, stagnant, or are they performed and re-interpreted? In a Latin American context, "Latinidad" is identified through various cultural markers such as memory, dance, and music. Arguably, labeling someone with a "Latina/o" identity, presupposes culture as something paradoxically static. In On Latinidad: U.S Latino Literature and the Construction of Ethnicity, Marta Caminero-Santangelo deconstructs the very notion of "Latinidad," and suggests that "most savvy commentators now disavow (at least explicitly) the notion of an essential Latino identity-- after all, we know that even gender and national identities are not 'essential' (there is no defining female 'soul' or inherent American 'spirit')" (4). Just as gender "is what is put on, invariably, under constraint, daily and incessantly, with anxiety and pleasure ${ }^{2}$," culture also has the ability to be performed and "put on." There is no Culture that absolutely defines a person's origin, heritage, or ethnicity. Latin American culture is not something inherited neither biologically nor genetically

\footnotetext{
2 Judith Butler's "Performance Acts and Gender Constitution." 531.
} 
and should be viewed rather as a site of movement and interpretation. To believe in an unchangeable and inherited Latinidad would support both biological and cultural essentialism, which automatically result in a stereotype-laden discourse and oppression of anyone who strays from what is considered the default identity. These forms of essentialism result in violent identity politics, as categorical lines are drawn creating binaries of what is and what is not. These legitimatizing characteristics play a crucial role in dictating ethnicity, gender, and sexuality.

Essentialized culture results in categorized ethnic groups based on race, birthplace, citizenship, and more. These labels further limit the ways in which culture is viewed, and confine an entire ethnic group to one generalized umbrella-term. Are these labels actually indicative of who one is? That is, does the term "Latina" or "Hispanic" represent the millions of people referred to as such? This essentialized way of thinking results in believing that each label represents a monolithic, unified racialized community. The notion of an essential Latinx culture is most famously challenged in Gloria E. Anzaldua's Borderlands/ La Frontera, as she explores how if a woman were to stray from these norms that are socially and culturally constructed, she is considered a "mujer mala" (17). Essentialistic labels fixate on who a Latina must be, and result in violent ramifications if one were to stray from them. We must remember that cultural identity and memory are flexible and forever-changing, not unlike a performance. 


\section{Latinx Dance Culture}

In terms of Latinx culture, dance is not only a marker of cultural identity but represents culture's transformative nature. In "Embodied Archives: Dance, Memory, and the Performance of Latinidad", Ramon Rivera-Servera explores the connections Latin dance has with identity, sexuality, and culture. Rivera-Servera posits that Latinx identities are witnessed and then transmitted through rhythm, all the while embody in the act of dance (10). Certain Latin American geographical areas are well known for their dance styles, as they provide a distinct cultural marker. For example, the Dominican Republic merengue, the Brazilian capoeira, and the Cuban conga.

Live events, such as a dance routine, represent and disseminate culture, yet are unable to be pinned down. In the collection Everynight Life: Culture and Dance in Latin/o America, Celeste Fraser Delgado and José Esteban Muñoz explore the relationships between Latinx culture, dance, and memory. Dance is viewed as an identification process that supplies histories written on the physical body. I argue that dance allows for the construction and deconstruction of identity and history as it exemplifies the embodied memory and inherent performativity of all cultures, here specially that of Latin America.

History, memory, and culture are often viewed as stagnant entities that are then used as identity markers. These entities are not questioned, and are regarded as factual If we were to view them as elements that are moveable rather than remain stable, we would allow the potential that comes with motion versus stasis. In "Rebellions of Everynight Life," Fraser Delgado speaks of the 
various ways "dance vivifies the cultural memory of a common context of struggle that bolsters a cultural identity itself forged through struggle and dance" (16). Dance offers a space for both improvisation and choreography, which supplies opportunities to share a myriad of stories that dismantle the notion of a monolithic, tyrannical voice.

The narrator of History is, more often than not, that of the person in a position of power who ultimately becomes the teller of the singular story. MichelRolph Trouillot's Silencing the Past: Power and the Production of History explains how History and the archive are created by historians, and result in the massive erasure of the powerless. Trouillot's seminal text interrogates the domination of historical tellings by arguing that "human beings participate in history both as actors and as narrators. The inherent ambivalence of the word "history" in many modern languages, including English, suggests this dual participation"(2). In this regard, dance routines can either be performed individually or collectively, which offer both independent and communal efforts of interpretation. Dance allows the participation of multiple people, which results in coalition-building and collectivity rather than an unchangeable, and thus tyrannical, solo narrative.

Dance is abundantly present in all cultures, however I argue that dance has a particular salience in Latin American cultures. Many Latin American cultures, such as Cuban culture, use dance as an expressive practice under various circumstances. In certain situations, dance is an act of resistance from a hegemonic structure whereas in others, it is a means of celebration and the creation of a communal uprising. Protest performances such as this are 
discussed in Ramon Rivera-Servera's Performing Queer Latinidad: Dance, Sexuality, Politics. In his ethnographic study, Rivera-Servera bears witness to countless contemporary Latinx performances that represent the emergence of queer Latinx identities in the States (6). Many Latin American cultures, such as Cuban, Mexican, and Argentine, are known for their styles of dance, and attempt to recreate a cultural body and collective memory. Unlike a traditional literary or historical artifact, dance requires live participation. Participation extends outward and exhibits a cultural memory that does not allow itself to be captured. Dance serves as an intangible language regardless of the form, style, or number of participants.

Choreo-graphy, History, and Historiography

Music and dance make space for culture to be reproduced and recreated, through what Joseph Roach refers to as "surrogation ${ }^{3}$." Surrogation is a process that weaves together memory, performance, and substitution in an attempt to reconfigure and present collective memory. This is not to say that performance always already displays cultural memory, but rather it implies the opportunity for collective memory to come to fruition. Performances allow a means of expression and opens the possibility for cultural understanding. These communal practices work in ways that produce memories and retrieve untold histories that have been silenced. Productions such as these are exemplified as Joseph Roach's

\footnotetext{
${ }^{3}$ Joseph Roach's seminal performance studies text "Cities of the Dead: Circum-Atlantic Performance."
} 
memorably illuminates the Mardi Gras Indians as transmitters of cultural memory. A critical understanding of cultural memory and history involves both memory and creation. Historical, personal, and cultural memories have become "embodied in and through performances" (Roach xi), whether at a formal venue such as a theatre's stage or at a local carnival celebration on the street. Culture and history are carried out through various performative events, thus they bring these recollections forward as they are recreating them. This is not unlike rumberos and rumberas dancing in the barrios of Cuba.

I suggest that we value dance as a method of demystifying traditional tellings of History, and use them as a way to explore the distinction between history and historiography (or choreo-graphy). History's hegemonic discourse prioritizes a phallogocentric way of thinking, which results in the creation of a singular empowered subject and the many disempowered objects. History is thought to be essential, and leaves no room for multiple narratives, reinterpretation, or revision. As Chimamanda Adichie shared in her lecture "The Danger of a Single Story," "our lives, our cultures, are composed of many overlapping stories." She asserts that if we only focus on one perspective, we are unable to dismantle a monolithic cultural identity. We must challenge this way of thinking, and attempt to unsilence the voices that are lost in this hegemonic structure. It prioritizes motion over stasis in historical analysis, as dance provides a more than metaphorical challenge to a unidirectional hegemonic idea of History. Juxtaposing dance and history is then a way to acknowledge fluid, bodily interpretations of historical events, that are delegitimized. This juxtaposition 
would allow for dance to actively re-create and perform history through rhythm, movement, and grace.

Our cultures have always already been embedded with traditions of music and dance that predates each and every one of us. In Latin American culture, dance and music are often of utmost importance and offer some semblance of a cultural identity. Dance is then a way of sharing and teaching cultural memory, as it literally re-members and re-creates practices. In VeVe Clarks' "Performing the Memory of Difference in Afro-Caribbean Dance," she discusses how all participants, including teacher, learner, and spectator, are actively re-producing cultural memory through dance practices. This communal effort of engaging and actively performing cultural memory allows for a myriad of voices and conversations rather than an independent privileged voice.

Re-creation, Corporealities, and Culture

Dance explores trauma, memory, and translocation as a site of history remembered on the physical body. The very notion that memory, both cultural and personal, involves re-creation is indicative of how malleable and fluid it is. In Everynight Life, Fraser Delgado and Munoz explain their project and the necessity to recognize dance as part of Latinx identity and cultural expectations. In the introduction of their book, they explore the ways in which "the body dancing to Latin American rhythms analyzes and articulates the conflicts that have crossed Latin/o American identity and history" (9). Dance transcends an archival system and transmits memories, political views, cultural history, and 
manifests a group's sense of identity. Dance and movement are not only a site of identification, but act as a conduit of a transformative history. History's opportunity to transform signifies one that is not fixed, and therefore essentialized. The monolithic discourse that History follows does not allow itself to be rewritten or reinterpreted. However, if we were to accept the body as a vessel of telling, then History's confines would be dismantled, allowing performance as an indicator. Corporeal reiterations of traditional culture resist being forgotten, as they transmit and posit future reinterpretations. Performance supplies a mnemonic remembering in an attempt to revive cultural and collective memory that are omitted from History and the archive.

Historically, Afro-Caribbean dances specifically dismantle and resist hegemony and linearity, insofar as they move against the traditional writing constraints of Western history. Noting dance as a site of history would expand the scope with which we consider what is a legitimized telling of history. We must challenge the notion of linear History, as textual evidence is considered as the primary source, yet enslaved populations were forbidden to be literate. The fact that enslaved Africans were predominantly illiterate further problematizes the written word as the sole medium of telling History. As a result, musical expression, memory, and improvisation were/are all vessels of cultural and personal histories. These ways of remembering do not adhere to the traditional perceptions and conventions of History, and are therefore dismissed. Why does History have an unhealthy obsession with textual artifacts, yet neglect the body as a vehicle of telling? 
In Archive Fever, Jacques Derrida deconstructs the notion of archival History, and refutes the incessant obsession surrounding the archiving process. In Derrida's speech, he refers to this obsession as a fever in that "it is to have a compulsive, repetitive, and nostalgic desire for the archive, an irrepressible desire to return to the origin, a homesickness, a nostalgia for return to the most archaic place of absolute commencement" (Derrida 91). The values of the archive lead us to neurotically search for Historical origins, but we must not neglect the physical body in these searches. Have bodies not been present throughout History?

Dance cannot be archived, for it is not something that can be collected. Unlike other arts, such as photography, visual arts, and literature, dance cannot be traced and does not leave a traditionally archivable record. In Unmarked: the Politics of Performance, Peggy Phelan refers to the ontological representation of dance in a historical context and asserts that "performance's only life is in the present. Performance cannot be saved, recorded, documented, or otherwise participate in the circulation of representations: once it does so, it becomes something other than performance" (146). Once a dance routine has been recorded, thus considered archivable material, it is no longer a performance. Considering the dancing body as a source of history values transformation and multiplicity rather than fixity and a unified truth, the latter of which leads to subjugation and oppression. Dance recalls and reinterprets cultural memory. 
These lived experiences, or what Paul Gilroy refers to as "lived crises ${ }^{4}$, encompass the dancing body's improvised negotiations of struggle and resistance. We must analyze and access live performance as a legitimate source of history remembered.

A dancing body does not only represent history, but resists any attempts to be controlled and constrained. Performances are in some sense linguistically irretrievable, which ultimately make every interpretation a re-interpretation. Just as our interpretations of written texts change upon every read, our perceptions of a dance routine will never be the same twice. Hence, every interpretation becomes a re-interpretation. While dance routines do involve certain rules and choreographed steps, it is impossible for a dance to be performed exactly the same twice. Muscle memory plays a pivotal role in dance, causing it to appear as though it is the same, however our readings of a dance will almost necessarily change. Placing dance and performativity as a text allows us to read the body as a vehicle of History.

Performance Studies and the Repertoire

Dances, such as the rumba, offer us acts of cultural and historical transfer, as they extend outward. Performance should be privileged as an act of cultural transfer ${ }^{5}$, as it actively functions as a vehicle of cultural memory. Dance, both choreographed and improvised, symbolizes the embodied practices that exist

\footnotetext{
${ }^{4}$ See Paul Gilroy's The Black Atlantic: Modernity and Double Consciousness. 40.

${ }^{5}$ Refer to Diana Taylor's "Acts of Transfer."
} 
within culture and memory. In the Archive and the Repertoire, Diana Taylor privileges performance just as much as historical and literary texts. Taylor's historical and cultural "repertoire" indicates that these embodied practices can participate in the unsilencing of voices, histories, cultures, and identities. To privilege performance, particularly dance, is to challenge the stagnant nature of traditional notions of memory and cultural identity. Memory, culture, and identity are as performative as dance: they are necessarily open to choreography and reproduction. The many dances of Latin America live within the space of the repertoire, and provide what Diana Taylor refers to as a "function [of a] vital act of transfer, transmitting social knowledge, memory, and a sense of identity through reiterated, or what Richard Schechner has called 'twice-behaved behavior"' (3). In Performance Studies: An Introduction," Schechner implores the academy to view performance as a critical term, as

"Performances - of art, rituals, or ordinary life - are 'restored behaviours', 'twice-behaved behaviour", performed actions that people train for and rehearse...But everyday life also involves years of training and practice, of adjusting and performing one's life roles in relation to social and personal circumstances" (29).

These events are unable to be retained or replayed at any means. For there is a blatant distinction between bearing witness to a salsa routine live in person and watching a previously recorded medium of the same dance. These performative ruptures illuminate the differences between the repertoire and the archive. 
Dance, then, encompasses improvisation and lived memory, and the archive refers to a tangible object that cannot reproduce the material it signifies.

Embracing these embodied behaviors and performances privileges social memory and fluid notions of cultural identity, whereas Western Enlightenment traditions tend to rely solely on the accounts in textbook History. The traditional archive is prioritized to such an extent that it neglects other forms of memory. To give in to this way of thinking would be to disregard all forms of memory that are not within the boundaries of the archive. Performances decolonize the hegemonic tellings of History, as many voices are inevitably silenced within the archive. The archive should be reworked in order to include an understanding of Latin American culture, rather than fixed within the standards of traditional History.

Dance is a way in which culture represents itself on the body. In many U.S Latinx cultures, different styles of dance not only result in a communal cultural identity, but are proactive in rejecting a hegemonic and tyrannical power. Dance and music supply an opportunity for Latin American communities to create themselves through performances, regardless of gender, sexual, racial, and class coordinates. Viewing the expressive body as a text broadens the scope with which we can identify and explore various facets of culture and cultural memory. Reading these dances works in a way of identifying the body, and serves as a marker for the production of gender, race, class, sexuality, etc. 
The Role of Dance in the New World

The role of dance in the New World was abundantly present amongst the enslaved, as different styles of dance were crucial to communicating with each other. Detached from their home country, subjugated enslaved were often unable to relate to one another as they rarely spoke the same language. There were many linguistic misinterpretations which inevitably led to insufficient means of communication. Physical movements offered the potential, to connect with each other and served as a central means of communication. Bodily movements opened the possibility to communicate with each other. Dance and music were universal and did not rely on oratory language to communicate with one another. These performances serve as distinct vessels of Caribbean history and should be acknowledged as such. These performances allow multiple expressions and perceptions of an embodied cultural memory as lived experiences are expressed through the body, transmitting social identity and enactments of history.

In "The Repeating Island: The Caribbean and the Postmodern Perspective," Antonio Benitez Rojo places emphasis on improvised cultural performance, as he believes they are the embodiment of a limitless telling of the Caribbean. For if there are no set structures for the ways in which we view culture, we can access it through methods of improvisation. He notes that the Caribbean rhythm portrays a metarhythm, made up of music, language, dance, etc. These methods of chaos perform in ways that resist violence and work in ways to eliminate the binaries that have been enforced by colonial discourse. "Chaos" refers to Rojo's redefinition of the term as he uses it to signify 
"everything that repeats, reproduces, grows, decays, unfolds, flows, spins, vibrates, seethes"(3). Music and dance have no borders which exemplify the false restrictions that are esoterically used to legitimize History. There is no singular narrative to Historical accounts, yet we live in a world that believes in this restriction. Accepting multiple methods and communal tellings will expand our knowledge of historical events.

\section{Cuban Rumba and Dance Culture}

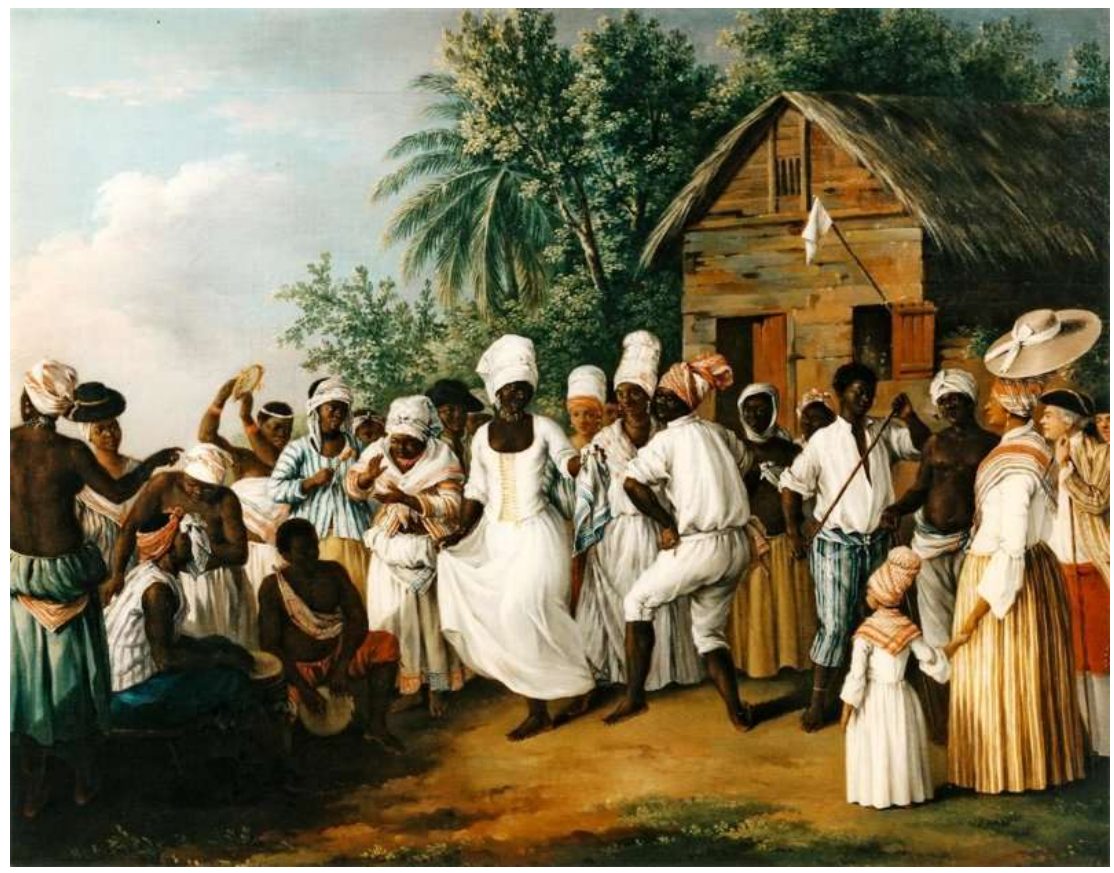

Brunias, Agostino. Handkerchief dance on the island of Dominica. Easel Painting. ARTstor. 17 May 2013.

Cultural memory relies on various aspects to take shape. In a Latinx context, dance and music are often two of the most important. Caribbean and Atlantic Diaspora have had a substantial influence on culture and performances on the islands. In Cuba, there are various dances that indicate the cultural, and 
national, identity of the island. Whether choreographed or improvised, dances such as the rumba, conga, and bolero offer the space to embody the memory of the island and re-present African ancestry with their practices. These folkloric dances require the participation of many, which allows for a communal telling of history. Each dance has received universal attention and exhibits what is perceived as Cuban identity, or Cuban-ness, with its performances. These dances are representative of embodied cultural memory, as they display bodily, political, spiritual, and emotional contexts within their iterations. Within these culturally specific dance sequences, other facets of identity, such as race, gender, class, and sexuality are actively disseminated.

Rumba is one of the most influential dance styles in Cuban culture and the island's history. The important Cuban folkloric dance has seminal importance in systematically articulating the nation's cultural image. While the term "rumba" is difficult to define, many scholars have attempted to define what it means. AfroCuban scholar Fernando Ortiz defines the rumba as being "a dance of Cuban origin with African antecedents" (11). There are also other derivatives of the term, such as rumberos that refer to the dance participants and rumbanchear which suggests a social gathering where the rumba will be performed. While the commercial style of rumba follows ballroom steps, there are many different iterations of the folkloric dance.

Of all the popular Cuban dance styles, the rumba has been problematized the most, both socially and culturally. Peter Manuel's Caribbean Currents: Caribbean Music from Rumba to Reggae explores various forms of the rumba, 
and refers to it as having derived "from secular dances cultivated by the Congolese slaves in Cuba" (28). Many attribute rumba to be inherently coming to terms with one's "Cuban-ness," yet do not consider the importance of its past. For to perform the rumba in the "correct form" is said to give direct insight into Cuban culture itself. Performing this dance can play a vital role in the authenticating of Cuban culture. As with any dance, rumba's performance has been commodified and appropriated, as its emergence has resulted in becoming an authenticating tool of Havana, Cuba. The unofficial national dance emerged in working-class communities, who congregated in the barrios of Cuba. There was certainly a negative stigma attached to these performances, as they were often criticized and easily racialized and equated with poverty, and therein maligned. Rumba is a stylistic form that includes both vocal chanting and physical movements. The chanting, or canto, of rumba often includes extremely political commentary, which stems from the origin of the dance itself. Dances, such as the rumba, are conventionally and reductively viewed as a social act, thus having no ties to politics or History. However, dance is linked to politics, religion, and culture as performances can portray acts of resistance. Dance occurs all over the world, thus is imbued with many aspects of politics, societal issues, and culture. Dance styles are affected by their surroundings and portray an amalgam of their environment. As the world changes, dance and music continue to transform.

Rumba is an ideal dance style to consider a site of history, as it began as a form resistance against the colonizers. At the end of the eighteenth century, many enslaved Africans were in Havana, or La Habana, and collectively 
produced the rumba, fueled with syncopated rhythms and anguish. While acts of rebellion were nearly impossible, recreational music and dance offered outlets of expression and protest. The majority of these performances were planned in advance, so people could join and create a communal expression of their sorrows, laments, and frustrations. The performances did not end with slavery, for post-emancipation they continued to supply a spatial solace and an opportunity for communal gathering. Politically, the rumba's power was viewed as the angst of the marginalized, as Cuban president Gerardo Machado signed legislation that banned any carnival related activities in 1925. Machado outlawed any public activity that employed "drums or analogous musical instruments of African nature," while also outlawing "bodily contortions that offended morality ${ }^{6} . "$ The power that the rumba had in the telling of an enslaved past was obviously present, clearly indicated by the fact that Machado banned its performances. Legislation certainly did not halt these dances, as they continuously occurred and reenacted a culture that the powers at play attempted to silence.

Dance in U.S Latinx Literature

The archive of U.S Latinx literary works that refer to dance is vast ${ }^{7}$. Dancing reflects a multitude of aspects, such as identification factors,

\footnotetext{
${ }^{6}$ Robin Moore's Nationalizing Blackness: Afrocubanismo and Artistic Revolution in Havana, 1920-1940. 72.

7 These works include, but are certainly not limited to, the danzon in Ana Menendez's In Cuba I Was a German Shepherd, the salsa in Junot Diaz's The Brief Wondrous Life of Oscar Wao, ballet in Rosario Ferre's The Flight of the Swan, the mambo Achy Obejas' Memory Mambo, and the flamenco in Julia Alvarez's How the Garcia Girls Lost Their Accents.
} 
recollections of a lost homeland, or a marker of Latinidad. In the majority of these texts, the characters speak through this kinesthetic discourse in an attempt to perform their cultural memories. As noted by Celeste Fraser Delgado and Jose Esteban Munoz, Oscar Hijuellos' the Mambo Kings Play Songs of Love illuminates how rumba was vehicle of cultural resistance of enslaved peoples through Afro-Caribbean rhythms. In this novel, the rumba personifies the history of the forced migration of Africans as one of the main characters, César, traces the rumba and recounts how:

The slaves who first danced this were usually chained up at night by the ankle, so they were forced to limit their movements: when they danced their rumbas, but was with much movement of the hips and little movement of the feet. That's the authentic rumba from the nineteenth century, with drums and voices and melody lines that sound Spanish and African at the same time...(Hijuelos 279).

Hijuelos' use of this particular dance style accentuates rumba's ability to construct and deconstruct Cuba's History all at once. A dance that is known as a celebration of Cuban pride is one whose origin is pain and hardship. While this style supplies a lot of the celebratory aspects of the island, the truth behind the limited movements opens the door to a painful past. Firstly, the notion of chained ankles refers to the believed origin of the rumba itself. In Life's A Good Gig: A Gringo Musician's Journey Into The World Of Latin Music, John Cain researches Latinx music culture and its popularity in the United States. When referring to 
Cuban music and dance culture, Cain describes rumba's development as the enslaved Africans

"were often chained at the ankles. In the slave camps they would play their music and dance. With the chains on their ankles they couldn't do much footwork, so they would dance in a stationary position and move their hips. This became the rumba. Generations later after slavery was abolished, a new style of dance emerged- the mambo. Freer, and with more foot work, the dancers are no longer stationary and can cover more area. Mambo is said to be the rumba with the chains removed" (126).

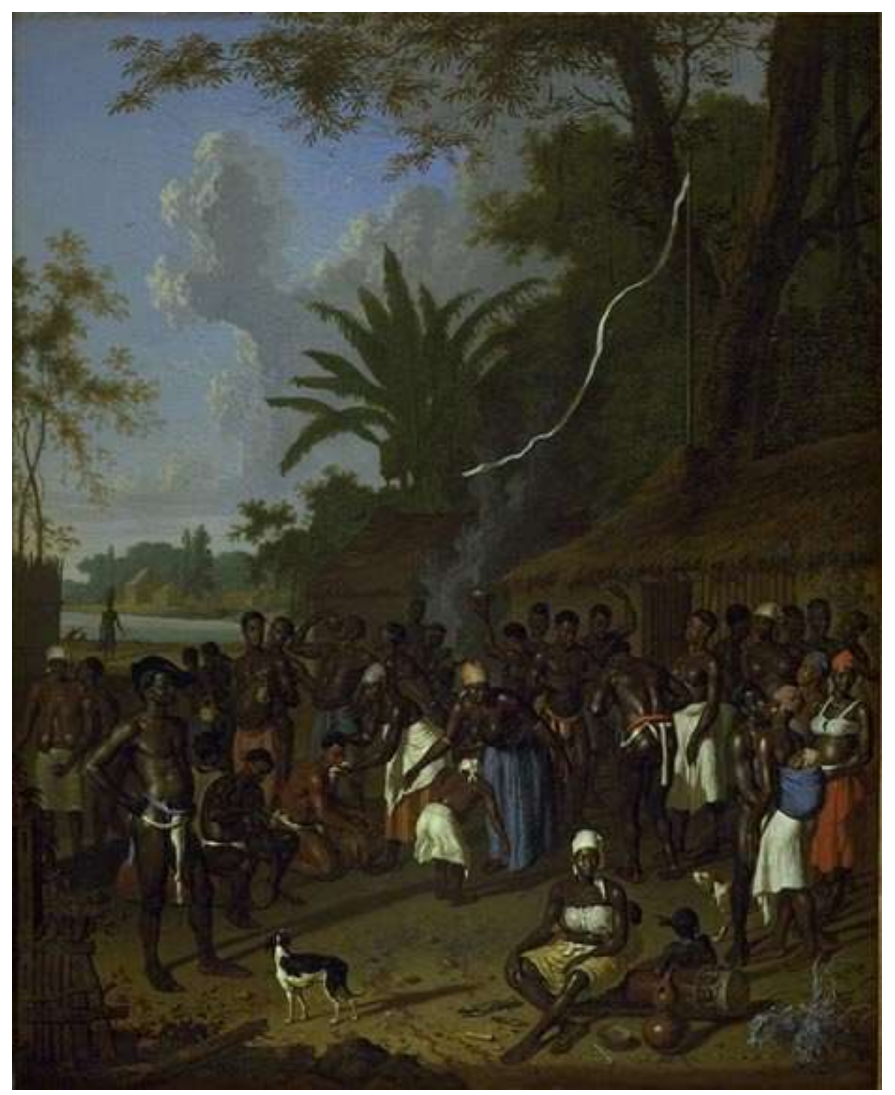

Dirk Valkenburg. "Slave Play" on a Sugar Plantation in Surinam. 1706-8. 
Cain's research explains rumba's origin while placing emphasis on the stylistic differences that have occurred over time. A dance formed by battling the constraints of enslavement has progressively shifted. Rumberos have altered this dance, which presents past trauma on the physical body. The dance cannot be captured, for it is forever changing and evolving ${ }^{8}$. The vocal content of rumba both resembles its African origin and extends towards Spanish, which represents its fluid nature and inability to be essentialized. The rumba is a quintessential gesture of transculturation, as it has been influenced and re-presented by various ethnic groups. Rumba's multicultural practice functions as a matrix of both colonialism and resistance, the here and the now, the past and the present.

\section{Conclusion}

Rumba's style exudes communal energy, as it is usually performed at social gatherings and is said to embody all of the elements of life, including but not limited to love, passion, sexuality, and spontaneity ${ }^{9}$. Rumba is systematically displayed as an image of Cuba, and fluctuates dependent on the social, cultural, and political climate of the island. Yvonne Daniel brings rumba to the forefront of her work, Rumba: Dance and Social Change in Contemporary Cuba, and emphasizes how politics and culture have actively influenced the ways in which it is performed. This embodied practice accomplishes what Fraser Delgado asserts as "dance sets politics in motion, bringing people together in rhythmic affinity

\footnotetext{
8 In "Hemispheric Performances," Diana Taylor discusses how rumba functions as a space of "identification and cross-identification" (267).

9 See Yvonne Daniel's "Rumba: Dance and Social Change in Contemporary Cuba."
} 
where identification takes the form of histories written on the body through gesture" (9). The discourse rumba creates works towards fragmenting an otherwise totalizing and colonized telling of History. These acts transgress a linear textual history, and supply multiple historical tellings with every performance.

The growth of rumba is a reminder of the multiple lived experiences that are historical tellings of the island. The rumba has so many interpretations and has received global popularity, which supplies multiple reads of its performance. There is potential in reading these dances as our main text, in an attempt to gain further knowledge on Cuba's history and cultural identity. In the first line of her song, "Quimbara," Celia Cruz sings of the rumba as an entity that repeatedly calls out to her. She sings

"La rumba me esta llamando bombo dile que ya voy.

Que me espere un momentico asi, mientras canto un guaguancó.

Dile que no es un desprecio, pues vive en mi corazón.

Mi vida es tan solo eso, rumba buena y guaguancó" (Cruz).

This verse translates to

"The rumba is calling me hype

tell him I'm coming. 
Let me wait a moment like that,

while I sing a rumba song.

Tell him it's not a disdain, because he lives in my heart.

My life is just that,

good rumba and rumba song" (Cruz, translation mine).

Cruz's "Quimbara" refers to the cultural relevance of the rumba in Cuban culture, all the while explaining the attachment people feel to the music and the dance style. She sings that the rumba "lives in my [her] heart," which connects the origin of the dance to the present day. Dance is always already surrounding us and calling to us.

Music and dance experiences, such as those of the rumba, foster and display political and cultural histories. Although textual History is validated within the archive as an absolute signifier of the past, it is the body that represent shifts of movement, transnationalism, and change. The ephemerality of the moving body performs history and allows movement to be witnessed rhetorically. Culture and History are constantly making and remaking themselves, through various physical acts. Corporeal and bodily performances should be considered as legitimate practices of the repertoire and witnessed as a pedagogy of cultural memory. Written histories, while prioritized, are not the final signifiers of History and should not be privileged as such. The physical body continues to move, whether through improvisation or choreographed precision. 
Dances, such as the rumba, exemplify historical, colonial, and diasporic shifts all at once. Positioning performance as a site of history acknowledges the transformations that the body exhibits with its movement. The repertoire supplies a space for cultural formation and the recounting of personal history. The reiterative and transformative processes reflect history and culture, as they are not fixed, but rather live in motion. Through bodily practices, we can interpret, and re-interpret, past memories and negotiate history. The body should be considered a fluid instrument of historical telling and an enactment of cultural identity. Dance performs a corporeal telling of History, and does not allowed itself to be constrained. Dances, such as the rumba, will forever-change and will keep calling us all. 


\section{References}

Adichie, Chimamanda Ngozi. "The Danger of a Single Story." TED Talk. 2009.

Alvarez, Julia. How the Garcia Girls Lost Their Accents. Algonquin Books, 2013.

Anzaldúa, Gloria. Borderlands: La Frontera. Aunt Lute Books, 2007.

Butler, Judith. "Performative Acts and Gender Constitution: An Essay in Phenomenology and Feminist Theory." Theatre Journal, vol. 40, no. 4, 1988, pp. 519-531.

Cain, John. Life's a Good Gig: a Gringo Musician's Journey Into the World of Latin Music. Enertia Publishing, 2007.

Caminero-Santangelo, Marta. On Latinidad: U.S. Latino Literature and the Construction of Ethnicity. Univ. Press of Florida, 2009.

Clark, Veve. "Performing the Memory of Difference in Afro-Caribbean Dance: Katherine Dunham's Choreography, 1938-1987." Stanford University. May 12, 1989.

Cruz, Celia. "Quimbara." Celia \& Johnny. Fania. 1974.

--. "Yo Vivire." Siempre Viviere. Sony. 2000.

Daniel, Yvonne. Caribbean and Atlantic Diaspora Dance Igniting Citizenship. University of Illinois Press, 2012.

--. Rumba: Dance and Social Change in Contemporary Cuba. Indiana Univ. Press, 1996.

Derrida, Jacques. Archive Fever: a Freudian Impression. Univ. of Chicago Press, 2016.

Dlaz, Junot. The Brief Wondrous Life of Oscar Wao. Riverhead Books, 2007.

Ferré, Rosario. The Flight of the Swan. Thorndike Press, 2002.

Gilroy, Paul. The Black Atlantic: Modernity and Double Consciousness. Verso, 2007.

Glissant, Édouard, and J. Michael Dash. Caribbean Discourse: Selected Essays. University Press of Virginia, 1989. 
Hijuelos, Oscar. The Mambo Kings Play Songs of Love. Farrar, Straus Giroux, 2015.

LeGoff, Jacques. History and Memory. Columbia University Press, 1996.

Manuel, Peter, and Michael D. Largey. Caribbean Currents Caribbean Music from Rumba to Reggae. Temple University Press, 2016.

Menéndez, Ana. In Cuba I Was a German Shepherd. Grove Press, 2002.

Moore, Robin Dale. Nationalizing Blackness Afrocubanismo and Artistic Revolution in Havana, 1920-1940. University of Pittsburgh Press, 1998.

Muñoz, Jose Esteban, and Celeste Fraser Delgado. Everynight Life: Culture and Dance in Latin/o America. Duke University Press, 1997.

Obejas, Achy. Memory Mambo: A Novel. Cleis Press, 2001.

Phelan, Peggy. Unmarked: the Politics of Performance. Routledge, 2004.

Rivera-Servera, Ramón. Performing Queer Latinidad: Dance, Sexuality, Politics. University of Michigan Press, 2012.

--."Embodied Archives: Dance, Memory, and the Performance of Latinidad." Smithsonian Center for Latino Initiatives, 2003.

Roach, Joseph. Cities of the Dead: Circum-Atlantic Performance. Columbia University Press, 1996.

Schechner, Richard. Performance Studies: An Introduction. London: Routledge. 2002.

Spivak Gayatri Chakravorty. Can the Subaltern Speak? Reflections on the History of an Idea. Columbia University Press, 2010.

Taylor, Diana. The Archive and the Repertoire: Performing Cultural Memory in the Americas. Duke University Press, 2007.

Trouillot, Michel-Rolph, and Hazel V. Carby. Silencing the Past: Power and the Production of History. Beacon Press, 2015. 